Check for updates

Cite this: RSC Adv., 2017, 7, 29330

Received 19th April 2017

Accepted 30th May 2017

DOI: 10.1039/c7ra04397j

rsc.li/rsc-advances

\title{
Preparation of magnetic metal organic framework nanocomposites for efficient and selective adsorption of hemoglobin from bovine blood $\uparrow$
}

\author{
Xin Yao, Xiangdong Ma, Xiaomei Gao and Li Jia (iD *
}

\begin{abstract}
We successfully synthesized magnetic metal organic framework nanocomposites by a facile approach. Carboxyl modified magnetic particles $\left(\mathrm{Fe}_{3} \mathrm{O}_{4}-\mathrm{COOH}\right)$ as the cores were first prepared by a solvothermal method. Then $\mathrm{Cu}_{3}(\mathrm{btc})_{2}$ as the shells were fabricated on the surface of $\mathrm{Fe}_{3} \mathrm{O}_{4}-\mathrm{COOH}$ by subsequent reactions in ethanol solutions of $\mathrm{CuSO}_{4}$ and 1,3,5-benzenetricarboxylic acid. The nanocomposites were found to enable efficient and selective adsorption of bovine hemoglobin $(\mathrm{BHb})$ based on an immobilized metal affinity chromatography mechanism. The nanocomposites possessed excellent magnetic responses (57.4 emu $\mathrm{g}^{-1}$ ) and demonstrated good aqueous dispersibility. They had narrow size distribution and the average size was about $15 \mathrm{~nm}$ in diameter. The amount of copper element in $\mathrm{Fe}_{3} \mathrm{O}_{4} @\left[\mathrm{Cu}_{3}(\mathrm{btc})_{2}\right]$ particles was measured to be $2.75 \%$. The Brunauer-Emmett-Teller surface area of $\mathrm{Fe}_{3} \mathrm{O}_{4} \mathrm{Q}\left[\mathrm{Cu}_{3}(\mathrm{btc})_{2}\right]$ was $95.1 \mathrm{~m}^{2} \mathrm{~g}^{-1}$. The adsorption kinetic data was well fitted using a pseudo-secondorder kinetic model and the adsorption equilibrium can be reached in $90 \mathrm{~min}$. The adsorption isotherm data was well described by the Langmuir equation. More importantly, the nanocomposites displayed superior adsorption capacity for $\mathrm{BHb}$ and the maximum adsorption capacity was as high as $6016 \mathrm{mg} \mathrm{g}^{-1}$. Furthermore, the nanocomposites showed high efficiency and good selectivity for isolation of abundant protein $\mathrm{BHb}$ from bovine blood. The results demonstrated that $\mathrm{Fe}_{3} \mathrm{O}_{4} \mathrm{a}\left[\mathrm{Cu}_{3}(\mathrm{btc})_{2}\right]$ nanocomposites would be a promising affinity material for histidine-rich proteins adsorption.
\end{abstract}

\section{Introduction}

As histidine (His)-rich proteins play important roles in various physiological processes, such as detoxification, antimicrobial responses, and the intrinsic pathway of coagulation cellular metal homeostasis, ${ }^{1}$ they have received more and more attention in practical applications. What is more, the level of His-rich proteins has been regarded as an indicator for many diseases, such as chronic kidney disease, thrombotic disorders, and malaria., ${ }^{2,3}$ However, the highly abundant His-rich proteins also have some disadvantages. For example, highly abundant His-rich proteins always submerge the low-abundant biomarkers in biomedical analysis, which will interfere with the detection of some compositions in blood. Thus, the removal of His-rich proteins in blood such as hemoglobin prior to analysis plays a critical role in the biomedical diagnosis study. Currently, immobilized metal affinity chromatography (IMAC) is the most frequently used method for the selective separation of His-tagged proteins, ${ }^{4-7}$ which relies on the interaction between an immobilized metal ion and electron

Ministry of Education Key Laboratory of Laser Life Science \& Institute of Laser Life, Science, College of Biophotonics, South China Normal University, Guangzhou 510631, China. E-mail: jiali@scnu.cn; Fax: +86-20-85216052; Tel: +86-20-85217070 $\uparrow$ Electronic supplementary information (ESI) available. See DOI: $10.1039 / \mathrm{c} 7 \mathrm{ra04397j}$ donor groups such as His located on the surface of proteins. However, the conventional chromatography is not suitable for direct handling biological samples due to its suspended particles and fouling components.

To circumvent the problem, magnetic particles (MPs) have drawn a great deal of interests in proteins separation ${ }^{8-11}$ due to their unique magnetic response, high surface area, good dispersion and easy surface modification. The MPs-based magnetic separation can be directly performed on complex samples. In addition, the MPs-based magnetic separation is time-effectiveness and labor-saving since MPs as adsorbents could be conveniently separated by applying an external magnetic field and no centrifugation step is needed to realize the phase separation. Thus, IMAC-based MPs would be desirable materials for separation of His-tagged proteins from complex samples since they combine the selectivity of IMAC and the convenience of MPs-based magnetic separation. IMAC-based MPs have been explored to separate His-tagged proteins. ${ }^{\mathbf{1 2 - 1 8}}$ In these IMAC-based MPs, nitrilotriacetic acid (NTA) and iminodiacetic acid (IDA) are the most commonly used metal ion chelating ligands. For example, $\mathrm{Cu}^{2+}$ or $\mathrm{Ni}^{2+}$ immobilized IDA-conjugated $\mathrm{Fe}_{3} \mathrm{O}_{4}$ particles were prepared for selective capture of His-rich bovine hemoglobin $(\mathrm{BHb}){ }^{15,16} \mathrm{Xu}$ and co-workers reported the preparation of nickelNTA-conjugated MPs for selective separation of His-tagged proteins. ${ }^{17,18}$ However, these IMAC-based MPs suffer from 
tedious and long synthetic steps, which make them not suitable for large-scale production, thus restricting their wide applications. Therefore, development of a facile method for preparation of new IMAC-based MPs for efficient and selective capture of His-rich proteins is still in great need.

Metal organic frameworks (MOFs) are a class of highly porous materials, which are fabricated by linking metal clusters or ions and organic linkers through covalent bonds. ${ }^{19}$ They have been widely applied in gas adsorption and separation, ${ }^{\mathbf{2 0 , 2 1}}$ catalysis, ${ }^{22}$ gas storage, ${ }^{23}$ sensor, ${ }^{24}$ biomedicine, ${ }^{25}$ and water remediation $^{26}$ because of their high porosity, tunable surface properties and excellent mechanical stability. Considering the unique properties of MOFs, MOFs-decorated MPs can integrate the favorable attributes of $\mathrm{Fe}_{3} \mathrm{O}_{4}$ nanoparticles and MOFs, showing great potential in sample pretreatment. ${ }^{27}$ MPs decorated by MOFs MIL-101, ${ }^{28} \mathrm{ZIF}-5,{ }^{29} \mathrm{ZIF}-8,{ }^{30}$ and MIL-100 (ref. 31) have been reported to preconcentrate polycyclic aromatic hydrocarbons, gibberellic acids, tetracyclines, and polychlorinated biphenyls from environmental samples. Very recently, Chen et al. synthesized MOF MIL-100 coated $\mathrm{Fe}_{3} \mathrm{O}_{4}$ nanoparticles, which were used as adsorbents for selective capture of phosphopeptides. ${ }^{32}$ These successful researches intrigued us to investigate the feasibility of MOFs-decorated MPs as adsorbents for separation of His-rich proteins based on IMAC since the low coordinated metal atoms on the external surface of MOFs-decorated MPs can chelate with His residues in His-tagged proteins. Furthermore, the high density of metal ions in the material would improve the adsorption capacity of the materials for His-tagged proteins. In IMAC, the transition metal ions, $\mathrm{Co}^{2+}, \mathrm{Zn}^{2+}, \mathrm{Cu}^{2+}$ and $\mathrm{Ni}^{2+}$, are the most often employed since they favorably coordinate with aromatic nitrogen atoms. The coordination strength of these metal ions by nitrogen-containing moieties follows the order $\mathrm{Cu}^{2+}>\mathrm{Ni}^{2+}>$ $\mathrm{Zn}^{2+} \sim \mathrm{Co}^{2+} .4$ Thus, the HKUST-1 $\left[\mathrm{Cu}_{3}(\mathrm{btc})_{2}\right]$ decorated MPs $\left(\mathrm{Fe}_{3} \mathrm{O}_{4} @\left[\mathrm{Cu}_{3}(\mathrm{btc})_{2}\right]\right)$ would be promising to efficiently and selectively adsorb His-tagged proteins.

Recently, we reported preparation of $\mathrm{Cu}^{2+}$-immobilized ethylenediaminetetraacetic acid modified magnetic particles $\left(\mathrm{Fe}_{3}-\right.$ $\mathrm{O}_{4} @ E D T A @ \mathrm{Cu}^{2+}$ ) for selective adsorption of $\mathrm{BHb} .{ }^{33}$ However, the little amount of $\mathrm{Cu}^{2+}$ immobilized on the surface of $\mathrm{Fe}_{3}$ $\mathrm{O}_{4} @$ EDTA limited the adsorption capacity of the particles towards BHb. In this study, an approach was developed for synthesis of core-shell nanocomposites $\mathrm{Fe}_{3} \mathrm{O}_{4} @\left[\mathrm{Cu}_{3}(\mathrm{btc})_{2}\right]$. The abundance of $\mathrm{Cu}^{2+}$ in $\mathrm{Cu}_{3}(\mathrm{btc})_{2}$ layer on the nanocomposites is expected to improve the adsorption capacity of $\mathrm{BHb}$. The nanocomposites were characterized by different techniques. The adsorption kinetics and isotherm of $\mathrm{Fe}_{3} \mathrm{O}_{4} @\left[\mathrm{Cu}_{3}(\mathrm{btc})_{2}\right]$ for $\mathrm{BHb}$ were studied. In addition, the practicality of $\mathrm{Fe}_{3} \mathrm{O}_{4}$ @ $\left[\mathrm{Cu}_{3}(\mathrm{btc})_{2}\right]$ in biological applications was evaluated by isolation of hemoglobin from bovine blood samples.

\section{Experimental}

\section{Materials}

1,3,5-Benzenetricarboxylic acid $\left(\mathrm{H}_{3}\right.$ btc) was obtained from Aladdin (Shanghai, China). Sodium chloride (NaCl), ammonium persulfate (APS), disodium hydrogen phosphate dodecahydrate $\left(\mathrm{Na}_{2} \mathrm{HPO}_{4} \cdot 12 \mathrm{H}_{2} \mathrm{O}\right)$, and sodium dihydrogen phosphate dihydrate $\left(\mathrm{NaH}_{2} \mathrm{PO}_{4} \cdot 2 \mathrm{H}_{2} \mathrm{O}\right)$ were purchased from Guangzhou Chemical Reagents Factory (Guangzhou, China). Sodium acrylate ( $\mathrm{Na}$ acrylate) was obtained from Beijing Universal Century Technology Company (Beijing, China). Ferric chloride hexahydrate $\left(\mathrm{FeCl}_{3} \cdot 6 \mathrm{H}_{2} \mathrm{O}\right)$, sodium acetate (NaAc), copper(II) sulfate pentahydrate $\left(\mathrm{CuSO}_{4} \cdot 5 \mathrm{H}_{2} \mathrm{O}\right)$, ethanol, ethylene glycol (EG), diethylene glycol (DEG) were purchased from Tianjin Damao Chemical Reagent Factory (Tianjin, China). Dopamine hydrochloride was obtained from Alfa Aesar (Tianjin, China). Bovine serum albumin (BSA, MW $67 \mathrm{kDa}$, pI 4.7) and $\mathrm{BHb}$ (MW 64.5 kDa, pI 6.8) were obtained from Shanghai Bio Science \& Technology Company (Shanghai, China). Lysozyme (Lyz, MW $14 \mathrm{kDa}$, pI 11.2) was purchased from GBCBIO Technologies Company (Guangzhou, China). Bovine blood was purchased from Guangzhou Ruite Biotechnology Company (Guangzhou, China), whose shelf life was one month at $4{ }^{\circ} \mathrm{C}$. Deionized water was prepared with an Elga water purification system (ELGA, London, UK).

\section{Synthesis of $\mathrm{Fe}_{3} \mathrm{O}_{4} @\left[\mathrm{Cu}_{3}(\mathrm{btc})_{2}\right]$}

The procedure for preparation of $\mathrm{Fe}_{3} \mathrm{O}_{4} @\left[\mathrm{Cu}_{3}(\mathrm{btc})_{2}\right]$ is schematically illustrated in Fig. 1. Firstly, carboxyl modified magnetic particles $\left(\mathrm{Fe}_{3} \mathrm{O}_{4}-\mathrm{COOH}\right)$ were prepared by a solvothermal method. ${ }^{34}$ Briefly, $\mathrm{FeCl}_{3} \cdot 6 \mathrm{H}_{2} \mathrm{O}(2.16 \mathrm{~g})$ was dissolved in a bisolvent containing DEG $(75 \mathrm{~mL})$ and EG $(5 \mathrm{~mL})$ to form a clear solution. Then $\mathrm{Na}$ acrylate $(6 \mathrm{~g})$ and NaAc $(6 \mathrm{~g})$ were added to the solution and the mixture was vigorously stirred at room temperature for $1 \mathrm{~h}$ to form a dark yellow solution. After that, the solution was transferred to a Teflon-lined stainlesssteel autoclave $(50 \mathrm{~mL})$ and heated at $200{ }^{\circ} \mathrm{C}$ for $10 \mathrm{~h}$. The final products were washed three times with ethanol and water, respectively. Finally, the products were dried at $50{ }^{\circ} \mathrm{C}$ under nitrogen atmosphere for further use.

Secondly, $0.1 \mathrm{~g} \mathrm{Fe}_{3} \mathrm{O}_{4}-\mathrm{COOH}$ was dispersed in $20 \mathrm{~mL}$ ethanol by ultrasonication for $30 \mathrm{~min}$. Afterwards, $50 \mathrm{~mL} \mathrm{CuSO}_{4}$ ethanol solution $(10 \mathrm{mM})$ was added to the $\mathrm{Fe}_{3} \mathrm{O}_{4}-\mathrm{COOH}$ solution and stirred at $600 \mathrm{rpm}$ and $70{ }^{\circ} \mathrm{C}$ for $15 \mathrm{~min}$. Then $50 \mathrm{~mL} \mathrm{H}$ btc ethanol solution $(10 \mathrm{mM})$ was added and the mixture was vigorously stirred at $70{ }^{\circ} \mathrm{C}$ for $30 \mathrm{~min}$. The final product $\mathrm{Fe}_{3} \mathrm{O}_{4}$ @ $\left[\mathrm{Cu}_{3}(\mathrm{btc})_{2}\right]$ were separated with a magnet and washed several times with ethanol and water, then dried under nitrogen atmosphere at $50{ }^{\circ} \mathrm{C}$.

\section{Characterization}

TEM images of $\mathrm{Fe}_{3} \mathrm{O}_{4} @\left[\mathrm{Cu}_{3}(\mathrm{btc})_{2}\right]$ were implemented on a JEM2100HR transmission electron microscope (JEOL, Tokyo,

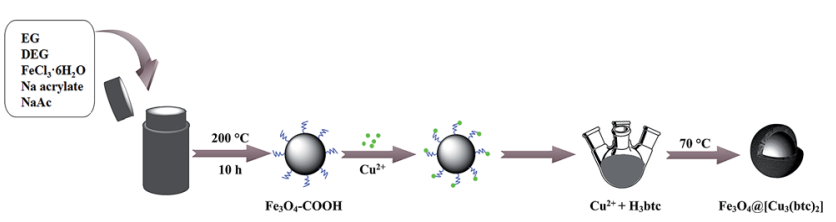

Fig. 1 Schematic illustration of the process for preparation of $\mathrm{Fe}_{3} \mathrm{O}_{4} \mathrm{a}$ $\left[\mathrm{Cu}_{3}(\mathrm{btc})_{2}\right]$. 
Japan). SEM and EDX micrographs were obtained on a field emission scanning electron microscope (Nova Nano SEM 430, PANalytical, Almelo, Netherlands). Magnetization curves of $\mathrm{Fe}_{3} \mathrm{O}_{4}-\mathrm{COOH}$ and $\mathrm{Fe}_{3} \mathrm{O}_{4} @\left[\mathrm{Cu}_{3}(\mathrm{btc})_{2}\right]$ particles were measured on a vibrating sample magnetometer (PPMS-9, Quantum Design, San Diego, USA) at room temperature and an applied field of $20 \mathrm{kOe}$. The nitrogen adsorption isotherms of samples were obtained at $77 \mathrm{k}$ with automated surface area and pore size analyzer (ASAP 2020, Micromeritics, Atlanta, USA). The zeta potential was measured on Zetasizer Nano-ZS (Malvern, Worcestershire, UK). The FT-IR spectra were recorded on a Nicolet iS50 FT-IR spectrometer (Madison, Wisconsin, USA). XRD was measured on Bruke D8 (Bruker AXS, Karlsruhe, Germany). X-ray photoelectron spectroscopy (XPS) was measured on Thermo ESCALAB 250Xi (Thermo Fisher Scientific, Massachusetts, USA) with an $\mathrm{Al}(\mathrm{K} \alpha=1486.7 \mathrm{eV}) \mathrm{X}$-ray source.

All capillary electrophoresis (CE) experiments were accomplished on a PACE-MDQ Beckman P/ACETM MDQ CE instrument (Beckman Coulter, Fullerton, CA, USA) equipped with a photodiode array detection UV detector. Data acquisition and analysis were performed with 32 Karat software (Beckman Coulter, Fullerton, CA, USA). Separations were performed in a polydopamine (PDA) coated column $(39.2 \mathrm{~cm}$ [effective length $29.2 \mathrm{~cm}] \times 50 \mu \mathrm{m}$ i.d.) at $25{ }^{\circ} \mathrm{C} .{ }^{35}$ Phosphate buffer solution (PBS, $20 \mathrm{mM}$, pH 2.5) was used as the background solution. The sample was injected at 0.5 psi for $5 \mathrm{~s}$ and separated by applying $-20 \mathrm{kV}$. The detection wavelength was set at $214 \mathrm{~nm}$. All solutions used in electrophoresis experiments were deaerated by ultrasonication prior to use. The quantitation analysis for proteins was carried out based on the linear relationship of the peak area of each protein with the concentration.

A PDA coated capillary was prepared by two steps. Firstly, a new uncoated capillary was preprocessed by rinsing with $1.0 \mathrm{M} \mathrm{HCl}(2 \mathrm{~h})$, followed by water $(0.5 \mathrm{~h}), 1.0 \mathrm{M} \mathrm{NaOH}(2 \mathrm{~h})$, water $(0.5 \mathrm{~h})$, and acetone $(0.5 \mathrm{~h})$ at a flow rate of $10 \mu \mathrm{L} \mathrm{min}{ }^{-1}$. After that, the capillary was dried with nitrogen at $180^{\circ} \mathrm{C}$ for $3 \mathrm{~h}$. Secondly, the dopamine solution $\left(7.7 \mathrm{mg} \mathrm{mL}^{-1}\right)$ was constituted by dissolving dopamine hydrochloride in $10 \mathrm{mM}$ Tris- $\mathrm{HCl}$ buffer (pH 8.5) containing $4.0 \mathrm{mg} \mathrm{mL}^{-1}$ APS. Afterwards, the dopamine solution was charged in the pretreated capillary and reacted at $40{ }^{\circ} \mathrm{C}$ for $12 \mathrm{~h}$, and then the PDA coatings were formed. The PDA coated capillary was dried with nitrogen at $40{ }^{\circ} \mathrm{C}$ for $12 \mathrm{~h}$. Subsequently, it was rinsed with $10 \mathrm{mM}$ Tris- $\mathrm{HCl}$ (pH 7.0) and water to get rid of the unreacted moieties. Between runs, the PDA coated capillary was rinsed with separation buffer for $3 \mathrm{~min}$. The PDA coated capillary was rinsed and stored in $10 \mathrm{mM}$ Tris-HCl (pH 7.0) at the end of each day.

\section{His-rich BHb adsorption studies}

$\mathrm{BHb}$ was chosen as a model His-rich protein to investigate the influences of size of $\mathrm{Fe}_{3} \mathrm{O}_{4} @\left[\mathrm{Cu}_{3}(\mathrm{btc})_{2}\right]$, contact time, solution $\mathrm{pH}$, ionic strength, and initial $\mathrm{BHb}$ concentration on the adsorption of $\mathrm{Fe}_{3} \mathrm{O}_{4} @\left[\mathrm{Cu}_{3}(\mathrm{btc})_{2}\right]$ for $\mathrm{BHb}$. Firstly, the $\mathrm{BHb}$ concentration was adjusted to a desired level $\left(1.8 \mathrm{mg} \mathrm{mL} \mathrm{mL}^{-1}\right)$ with the adsorption solution (20 mM PBS, pH 7.0), then $0.03 \mathrm{mg}$ $\mathrm{Fe}_{3} \mathrm{O}_{4} @\left[\mathrm{Cu}_{3}(\mathrm{btc})_{2}\right]$ were added to the $\mathrm{BHb}$ solution $(0.2 \mathrm{~mL})$.
The mixture was vibrated at room temperature for $90 \mathrm{~min}$. After magnetic separation, the concentrations of $\mathrm{BHb}$ in the initial solution and supernatant were measured by a microspectrophotometer (K5600, Beijing Kaiao Technology Development Company, Beijing, China) at $408 \mathrm{~nm}$. BHb had a maximum absorption peak at $408 \mathrm{~nm}$ and the linear relationship of the absorbance of $\mathrm{BHb}$ at $408 \mathrm{~nm}\left(A_{408}\right)$ against the BHb concentration $\left(C, \mathrm{mg} \mathrm{mL}^{-1}\right)$ was expressed as an equation, $A_{408}=4.812 C-0.1314\left(R^{2}=0.9942\right)$. The adsorbed amount of $\mathrm{BHb}$ was calculated according to the following equation:

$$
Q=\frac{\left(C_{0}-C_{\mathrm{S}}\right) V}{m}
$$

where $Q\left(\mathrm{mg} \mathrm{g}^{-1}\right)$ is the amount of BHb adsorbed, $C_{0}$ and $C_{\mathrm{S}}$ are the initial and equilibrium concentrations of $\mathrm{BHb}\left(\mathrm{mg} \mathrm{mL} \mathrm{m}^{-1}\right)$, respectively, $V(\mathrm{~mL})$ is the volume of $\mathrm{BHb}$ solution, and $m(\mathrm{~g})$ is the mass of $\mathrm{Fe}_{3} \mathrm{O}_{4} @\left[\mathrm{Cu}_{3}(\mathrm{btc})_{2}\right]$ used.

\section{Selectivity experiments}

In order to study the selectivity of $\mathrm{Fe}_{3} \mathrm{O}_{4} @\left[\mathrm{Cu}_{3}(\mathrm{btc})_{2}\right], \mathrm{BHb}, \mathrm{Lyz}$ and BSA were chosen as model proteins. As we all know, $\mathrm{BHb}$ is a His-rich protein, while other proteins possess less or no surface-exposed His residues. The mixed proteins solution was used to research the selectivity of $\mathrm{Fe}_{3} \mathrm{O}_{4} @\left[\mathrm{Cu}_{3}(\text { btc })_{2}\right]$ for His-rich proteins. The initial solution and the supernatant were analyzed by $\mathrm{CE}$, respectively.

\section{Real sample analysis}

Bovine blood sample was diluted 100-fold using $20 \mathrm{mM}$ PBS (pH 7.0). In order to verify the feasibility of $\mathrm{Fe}_{3} \mathrm{O}_{4} @\left[\mathrm{Cu}_{3}(\mathrm{btc})_{2}\right]$ in real samples, $\mathrm{Fe}_{3} \mathrm{O}_{4} @\left[\mathrm{Cu}_{3}(\mathrm{btc})_{2}\right](0.03 \mathrm{mg})$ were added to the diluted sample $(0.2 \mathrm{~mL})$ to remove hemoglobin under the optimized adsorption conditions. After magnetic separation, the diluted blood and the supernatant were analyzed by CE, respectively.

\section{Results and discussion}

\section{Characterization of $\mathrm{Fe}_{3} \mathrm{O}_{4} @\left[\mathrm{Cu}_{3}(\mathrm{btc})_{2}\right]$ particles}

The zeta potentials of $\mathrm{Fe}_{3} \mathrm{O}_{4} @\left[\mathrm{Cu}_{3}(\text { btc })_{2}\right]$ and $\mathrm{Fe}_{3} \mathrm{O}_{4}-\mathrm{COOH}$ particles were researched in $20 \mathrm{mM}$ PBS solutions over a $\mathrm{pH}$ range from 3.0 to 10.0 at $25{ }^{\circ} \mathrm{C}$. As shown in Fig. 2a, the magnitude of zeta potential of $\mathrm{Fe}_{3} \mathrm{O}_{4} @\left[\mathrm{Cu}_{3}(\mathrm{btc})_{2}\right]$ particles increased sharply with the increase of $\mathrm{pH}$ value in the $\mathrm{pH}$ range of 3.0-7.0. Beyond 7.0, the magnitude of zeta potential of the particles decreased slowly. Above $\mathrm{pH}$ 3.0, they took negative charges due to the existence of carboxyl groups in $\mathrm{Fe}_{3} \mathrm{O}_{4}$ @ $\left[\mathrm{Cu}_{3}(\mathrm{btc})_{2}\right]$. Fig. 2 showed that the effect of $\mathrm{pH}$ on the zeta potential of $\mathrm{Fe}_{3} \mathrm{O}_{4} @\left[\mathrm{Cu}_{3}(\mathrm{btc})_{2}\right]$ was different from that on $\mathrm{Fe}_{3} \mathrm{O}_{4}-\mathrm{COOH}$ particles, indicating that $\mathrm{Cu}_{3}(\mathrm{btc})_{2}$ was successfully modified on the surface of $\mathrm{Fe}_{3} \mathrm{O}_{4}-\mathrm{COOH}$.

The magnetic characterizations of the $\mathrm{Fe}_{3} \mathrm{O}_{4}-\mathrm{COOH}$ and $\mathrm{Fe}_{3} \mathrm{O}_{4} @\left[\mathrm{Cu}_{3}(\mathrm{btc})_{2}\right]$ particles were measured by VSM at $20 \mathrm{kOe}$, as shown in Fig. 2b. The magnetization saturation values of $\mathrm{Fe}_{3} \mathrm{O}_{4}-\mathrm{COOH}$ and $\mathrm{Fe}_{3} \mathrm{O}_{4} @\left[\mathrm{Cu}_{3}(\mathrm{btc})_{2}\right]$ particles were 60.9 and $57.4 \mathrm{emu}^{-1}$, respectively. This result indicated that these particles possessed excellent magnetic responses and they 

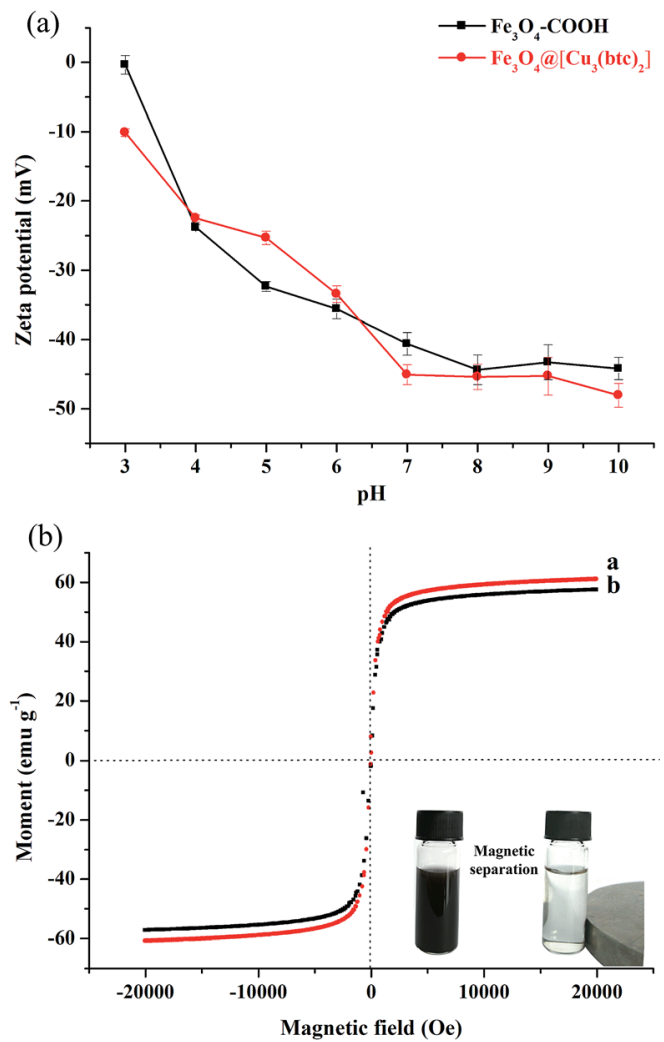

Fig. 2 (a) Zeta potentials of $\mathrm{Fe}_{3} \mathrm{O}_{4}-\mathrm{COOH}$ and $\mathrm{Fe}_{3} \mathrm{O}_{4} \mathrm{a}\left[\mathrm{Cu}_{3}(\mathrm{btc})_{2}\right]$ at different $\mathrm{pH}$ values $\left(n=3\right.$ ). (b) VSM curves of $\mathrm{Fe}_{3} \mathrm{O}_{4}-\mathrm{COOH}$ and $\mathrm{Fe}_{3} \mathrm{O}_{4} @\left[\mathrm{Cu}_{3}\left(\mathrm{btc}_{2}\right)\right]$ particles.

could be easily separated from aqueous solution in less than $15 \mathrm{~s}$ by applying an external magnetic field, as shown in the inset of Fig. 2b. In addition, the nanoparticles can be dispersed uniformly in aqueous solution to form a black and homogeneous solution. In comparison with $\mathrm{Fe}_{3} \mathrm{O}_{4}-\mathrm{COOH}$ particles, the decrease in the magnetization saturation value of $\mathrm{Fe}_{3} \mathrm{O}_{4}$ @ $\left[\mathrm{Cu}_{3}(\mathrm{btc})_{2}\right]$ particles demonstrated that $\mathrm{Cu}_{3}(\mathrm{btc})_{2}$ were successfully modified on the surface of $\mathrm{Fe}_{3} \mathrm{O}_{4}-\mathrm{COOH}$ particles.

The size and surface morphology information of $\mathrm{Fe}_{3} \mathrm{O}_{4} @$ $\left[\mathrm{Cu}_{3}(\mathrm{btc})_{2}\right]$ particles were directly observed by SEM and TEM images, as shown in Fig. 3a and b. The SEM images (Fig. 3a) demonstrated that $\mathrm{Fe}_{3} \mathrm{O}_{4} @\left[\mathrm{Cu}_{3}(\mathrm{btc})_{2}\right]$ nanoparticles were approximately spherical-shaped with a narrow size distribution. The TEM images (Fig. 3b) showed that the surface of $\mathrm{Fe}_{3} \mathrm{O}_{4} @$ $\left[\mathrm{Cu}_{3}(\mathrm{btc})_{2}\right]$ was irregular and the average size of the nanoparticle was about $15 \mathrm{~nm}$ in diameter.

The nitrogen physical adsorption-desorption isotherms of $\mathrm{Fe}_{3} \mathrm{O}_{4} @\left[\mathrm{Cu}_{3}(\mathrm{btc})_{2}\right]$ and $\mathrm{Fe}_{3} \mathrm{O}_{4}-\mathrm{COOH}$ were measured and used to determine the surface areas of these particles. As shown in Fig. 4a, the Brunauer-Emmett-Teller (BET) surface area of $\mathrm{Fe}_{3} \mathrm{O}_{4} @\left[\mathrm{Cu}_{3}(\mathrm{btc})_{2}\right]$ was calculated to be $95.1 \mathrm{~m}^{2} \mathrm{~g}^{-1}$, which had no significant difference from that of $\mathrm{Fe}_{3} \mathrm{O}_{4}-\mathrm{COOH}\left(97.3 \mathrm{~m}^{2}\right.$ $\mathrm{g}^{-1}$ ), as shown in Fig. S1. $\dagger$ The result indicated that the $\mathrm{Cu}_{3}(\mathrm{btc})_{2}$ coating was thin. The $\mathrm{Cu}_{3}(\mathrm{btc})_{2}$ coating can provide abundant binding sites for the adsorption of His-tagged proteins.

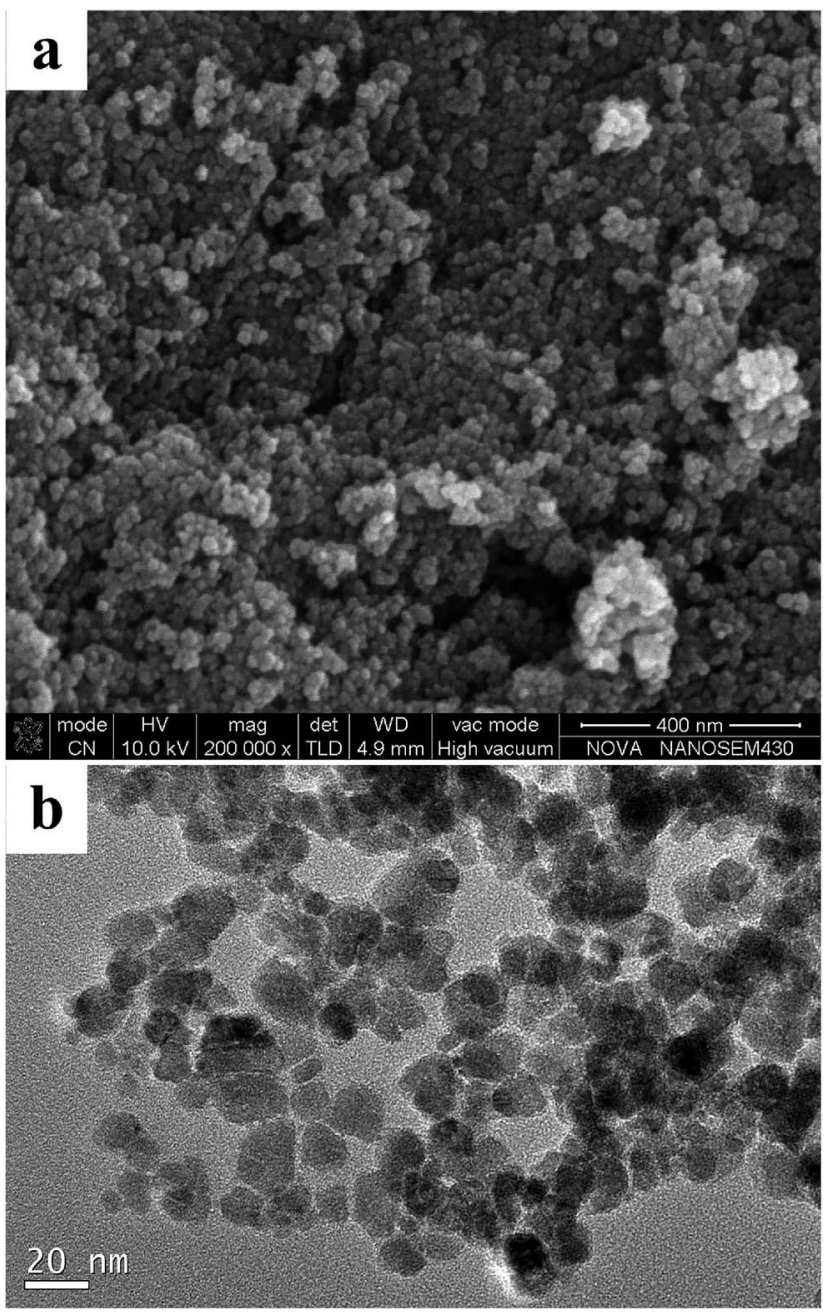

Fig. 3 SEM (a) and TEM images (b) of $\mathrm{Fe}_{3} \mathrm{O}_{4} @\left[\mathrm{Cu}_{3}(\mathrm{btc})_{2}\right]$ particles.

EDX analysis was used to investigate the immobilization of $\mathrm{Cu}_{3}(\mathrm{btc})_{2}$ on the $\mathrm{Fe}_{3} \mathrm{O}_{4}-\mathrm{COOH}$ particles. As shown in Fig. $4 \mathrm{~b}$, the EDX graph of $\mathrm{Fe}_{3} \mathrm{O}_{4} @\left[\mathrm{Cu}_{3}(\mathrm{btc})_{2}\right]$ particles revealed that $\mathrm{Cu}$ element existed in the particles. The amount of copper element in $\mathrm{Fe}_{3} \mathrm{O}_{4} @\left[\mathrm{Cu}_{3}(\mathrm{btc})_{2}\right]$ particles was measured to be $2.75 \%$. In contrast, $\mathrm{Cu}$ element content in $\mathrm{Fe}_{3} \mathrm{O}_{4} @ E D T A @ \mathrm{Cu}^{2+}$ was $1.23 \%{ }^{33}$ The amount of $\mathrm{Cu}$ element in $\mathrm{Fe}_{3} \mathrm{O}_{4} @\left[\mathrm{Cu}_{3}(\mathrm{btc})_{2}\right]$ was 2.24 times as large as that of $\mathrm{Fe}_{3} \mathrm{O}_{4} @ E D T A @ \mathrm{Cu}^{2+}$.

Fig. 4c provided the X-ray diffraction patterns of the $\mathrm{Fe}_{3} \mathrm{O}_{4}-$ $\mathrm{COOH}$ and $\mathrm{Fe}_{3} \mathrm{O}_{4} @\left[\mathrm{Cu}_{3}(\mathrm{btc})_{2}\right]$. In comparison with the pattern of $\mathrm{Fe}_{3} \mathrm{O}_{4}-\mathrm{COOH}$ particles, two extra peaks marked with asterisks at $2 \theta$ degree of near $8^{\circ}$ and $12^{\circ}$ appeared in the pattern of $\mathrm{Fe}_{3} \mathrm{O}_{4} @\left[\mathrm{Cu}_{3}(\mathrm{btc})_{2}\right]$, which correspond to the specific (200) and (222) planes of $\mathrm{Cu}_{3}(\mathrm{btc})_{2}$ lattice, respectively. The two tiny characteristic peaks of $\mathrm{Cu}_{3}(\mathrm{btc})_{2}$ demonstrated that $\mathrm{Fe}_{3} \mathrm{O}_{4}{ }^{-}$ $\mathrm{COOH}$ is the major component of the composites, which can be verified by the EDX analysis result.

The $\mathrm{Cu}_{3}(\mathrm{btc})_{2}$ coating on the surface of $\mathrm{Fe}_{3} \mathrm{O}_{4}-\mathrm{COOH}$ was further investigated with FT-IR, as shown in Fig. 4 d, which can provide another evidence for surface functionalization. In the FT-IR spectra of $\mathrm{Fe}_{3} \mathrm{O}_{4}-\mathrm{COOH}$, the bands located at $1632 \mathrm{~cm}^{-1}$ 


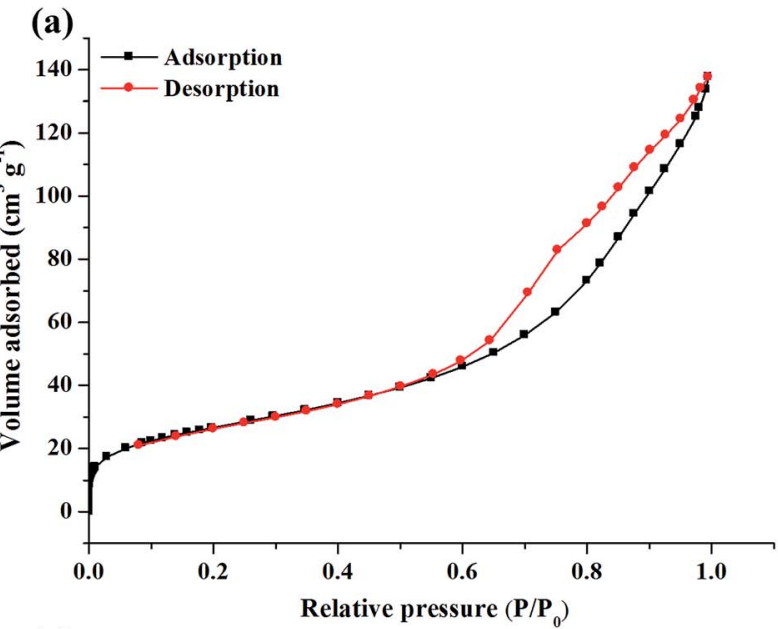

(c)

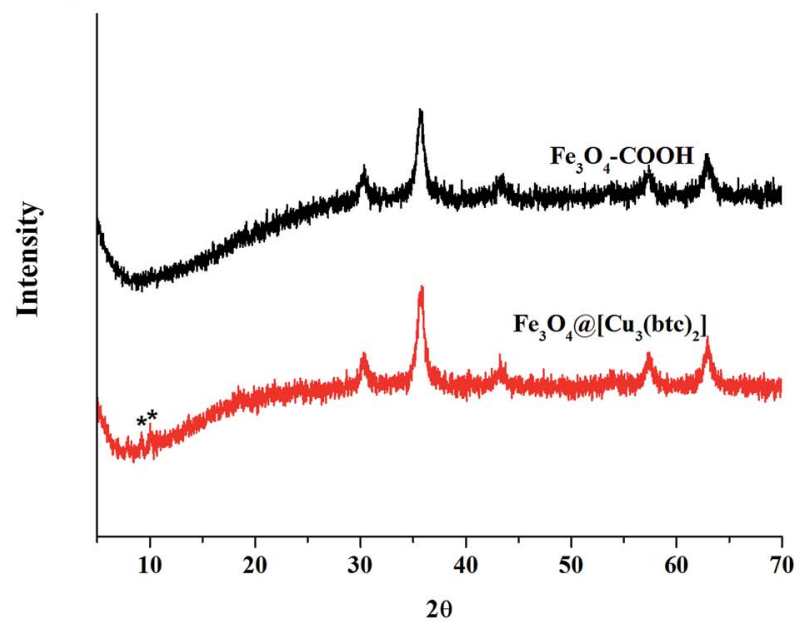

(b)

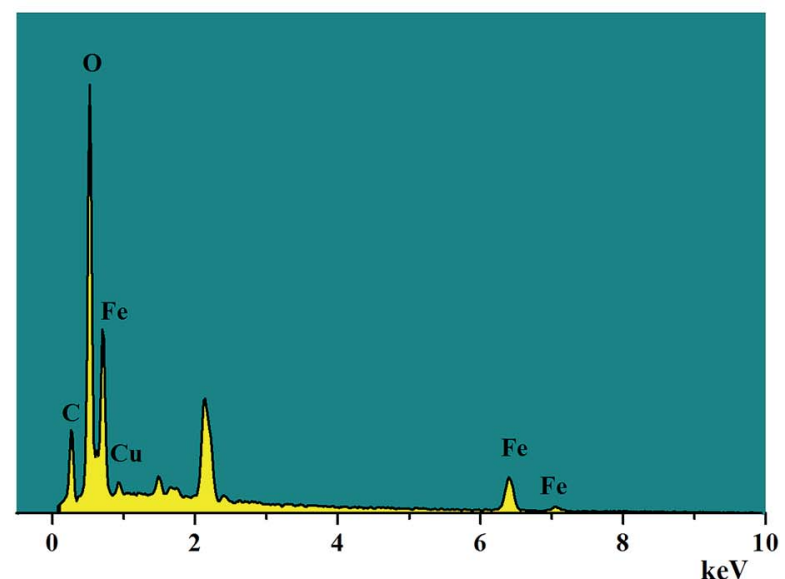

(d)

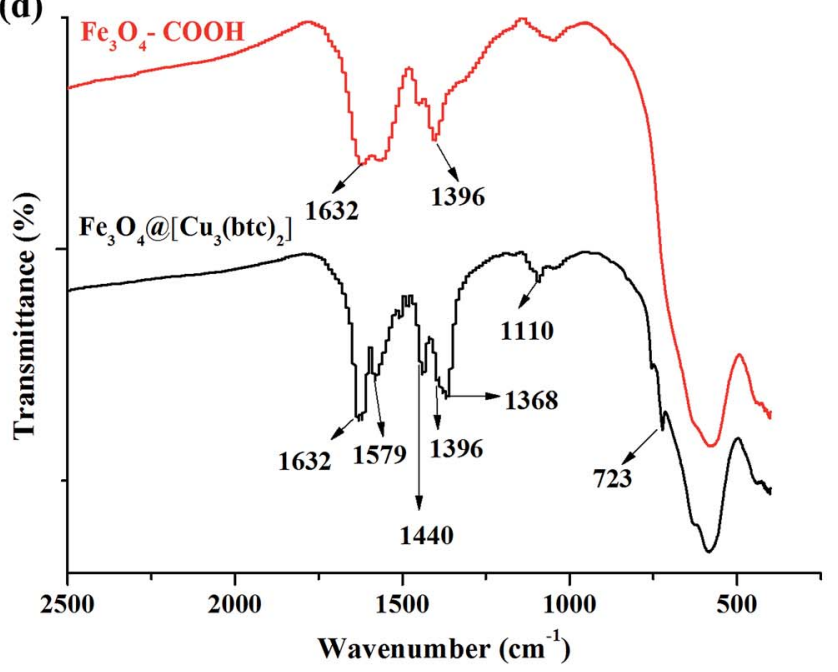

Fig. 4 (a) $\mathrm{N}_{2}$ adsorption-desorption isotherms of $\mathrm{Fe}_{3} \mathrm{O}_{4} \mathrm{Q}\left[\mathrm{Cu}_{3}(\mathrm{btc})_{2}\right]$ particles measured at $77 \mathrm{k}$. (b) EDX spectrum of $\mathrm{Fe}_{3} \mathrm{O}_{4} @$ @ [Cu $\left.(\mathrm{btc})_{2}\right]$ particles. (c) XRD patterns of $\mathrm{Fe}_{3} \mathrm{O}_{4}-\mathrm{COOH}$ and $\mathrm{Fe}_{3} \mathrm{O}_{4} @\left[\mathrm{Cu}_{3}(\mathrm{btc})_{2}\right]$. (d) FT-IR spectra of $\mathrm{Fe}_{3} \mathrm{O}_{4}-\mathrm{COOH}$ and $\mathrm{Fe}_{3} \mathrm{O}_{4} @\left[\mathrm{Cu}_{3}(\mathrm{btc})_{2}\right]$.

and $1396 \mathrm{~cm}^{-1}$ resulted from the carboxyl groups of $\mathrm{Fe}_{3} \mathrm{O}_{4}-$ COOH. In the FT-IR spectra of $\mathrm{Fe}_{3} \mathrm{O}_{4} @\left[\mathrm{Cu}_{3}(\mathrm{btc})_{2}\right]$, the bands at $1632 \mathrm{~cm}^{-1}, 1396 \mathrm{~cm}^{-1}$, and $1368 \mathrm{~cm}^{-1}$ resulted from the carboxyl groups of $\mathrm{Fe}_{3} \mathrm{O}_{4}-\mathrm{COOH}$ and btc in $\mathrm{Fe}_{3} \mathrm{O}_{4} @\left[\mathrm{Cu}_{3}(\mathrm{btc})_{2}\right]$. The bands at $1579 \mathrm{~cm}^{-1}$ and $1440 \mathrm{~cm}^{-1}$ represented the typical bands of phenyl $\mathrm{C}=\mathrm{C}$ ring stretch of btc linker in $\mathrm{Fe}_{3} \mathrm{O}_{4}$ @
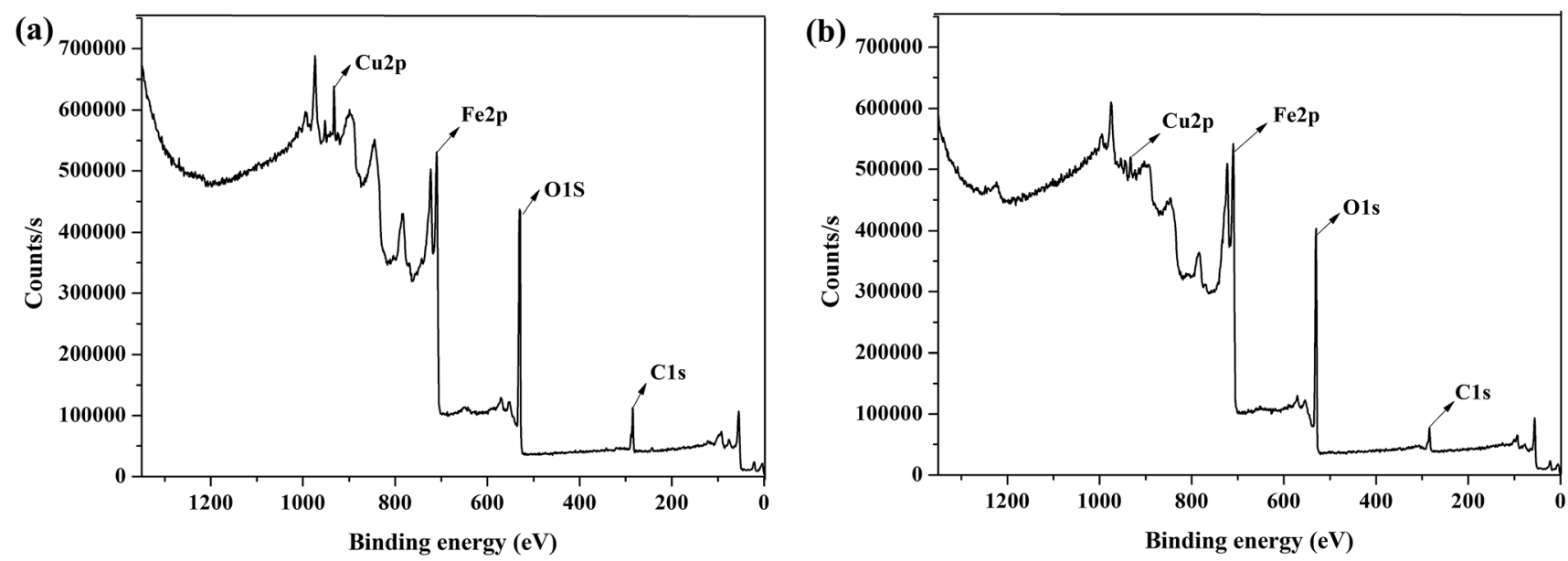

Fig. 5 XPS full spectra of fresh (a) and etched (b) $\mathrm{Fe}_{3} \mathrm{O}_{4} \mathrm{a}\left[\mathrm{Cu}_{3}(\mathrm{btc})_{2}\right]$. 
$\left[\mathrm{Cu}_{3}(\mathrm{btc})_{2}\right]$. In addition, the band located at $1110 \mathrm{~cm}^{-1}$ was related to $\mathrm{C}-\mathrm{O}-\mathrm{Cu}$ vibration in the MOF. ${ }^{19}$ Other finger print band at $723 \mathrm{~cm}^{-1}$ could be assigned to $\mathrm{C}-\mathrm{H}$ in benzene ring. ${ }^{36}$ The results demonstrated that $\mathrm{Cu}_{3}(\mathrm{btc})_{2}$ were successfully coated on the surface of $\mathrm{Fe}_{3} \mathrm{O}_{4}-\mathrm{COOH}$.

To reveal the core-shell type structure of $\mathrm{Fe}_{3} \mathrm{O}_{4} @\left[\mathrm{Cu}_{3}(\mathrm{btc})_{2}\right]$, XPS of the fresh $\mathrm{Fe}_{3} \mathrm{O}_{4} @\left[\mathrm{Cu}_{3}(\mathrm{btc})_{2}\right]$ and etched $\mathrm{Fe}_{3} \mathrm{O}_{4} @$ $\left[\mathrm{Cu}_{3}(\mathrm{btc})_{2}\right]$ using argon ion were performed. As shown in the XPS full spectra (Fig. 5), the signals of $\mathrm{Cu}, \mathrm{Fe}, \mathrm{O}$ and $\mathrm{C}$ elements were observed. The signal of $\mathrm{Cu}$ element in the fresh $\mathrm{Fe}_{3} \mathrm{O}_{4} @$ $\left[\mathrm{Cu}_{3}(\text { btc })_{2}\right]$ (Fig. 5a) was significantly different from that in the etched $\mathrm{Fe}_{3} \mathrm{O}_{4} @\left[\mathrm{Cu}_{3}(\mathrm{btc})_{2}\right]$ (Fig. 5b). Atomic analysis displayed that the percentage of copper ( $\mathrm{Cu} 2 \mathrm{p})$ in the fresh and etched samples were $2.70 \%$ and $1.48 \%$, respectively. The content of $\mathrm{Cu}$ element in the fresh sample measured by XPS was in good agreement with that determined by EDX (2.75\%). In comparison with the fresh sample, the decrease of $\mathrm{Cu}$ content in the etched sample demonstrated that $\mathrm{Cu}_{3}(\mathrm{btc})_{2}$ was successfully immobilized on the surface of $\mathrm{Fe}_{3} \mathrm{O}_{4}-\mathrm{COOH}$ and the $\mathrm{Fe}_{3} \mathrm{O}_{4}$ @ $\left[\mathrm{Cu}_{3}(\mathrm{btc})_{2}\right]$ particles were core-shell type structure.

\section{Adsorption of $\mathrm{BHb}$ by $\mathrm{Fe}_{3} \mathrm{O}_{4} @\left[\mathrm{Cu}_{3}(\mathrm{btc})_{2}\right]$ particles}

Effect of size of $\mathrm{Fe}_{3} \mathrm{O}_{4} @\left[\mathrm{Cu}_{3}(\mathrm{btc})_{2}\right]$. The $\mathrm{Fe}_{3} \mathrm{O}_{4}-\mathrm{COOH}$ size can be tuned by using different volume ratios of EG to DEG in the bisolvent system while keeping other reaction parameters constant. ${ }^{34}$ The $\mathrm{Fe}_{3} \mathrm{O}_{4}-\mathrm{COOH}$ size decreased with increasing portion of DEG. Then, $\mathrm{Cu}_{3}(\mathrm{btc})_{2}$ was respectively modified on the different sizes of $\mathrm{Fe}_{3} \mathrm{O}_{4}-\mathrm{COOH}$ particles. The results demonstrated that the adsorption capacity of $\mathrm{Fe}_{3} \mathrm{O}_{4}$ @ $\left[\mathrm{Cu}_{3}(\mathrm{btc})_{2}\right]$ particles for $\mathrm{BHb}$ increased with the decrease of particle size, as shown in Fig. S2. $\dagger$ While, the magnetization saturation value of $\mathrm{Fe}_{3} \mathrm{O}_{4} @\left[\mathrm{Cu}_{3}(\mathrm{btc})_{2}\right]$ decreased with the decrease of particle size. Our results showed that when the volume ratio of EG to DEG was $1: 15$, the prepared $\mathrm{Fe}_{3} \mathrm{O}_{4}$ @ $\left[\mathrm{Cu}_{3}(\mathrm{btc})_{2}\right]$ can not only offer high adsorption capacity for BHb, but can also have strong magnetic response to an externally

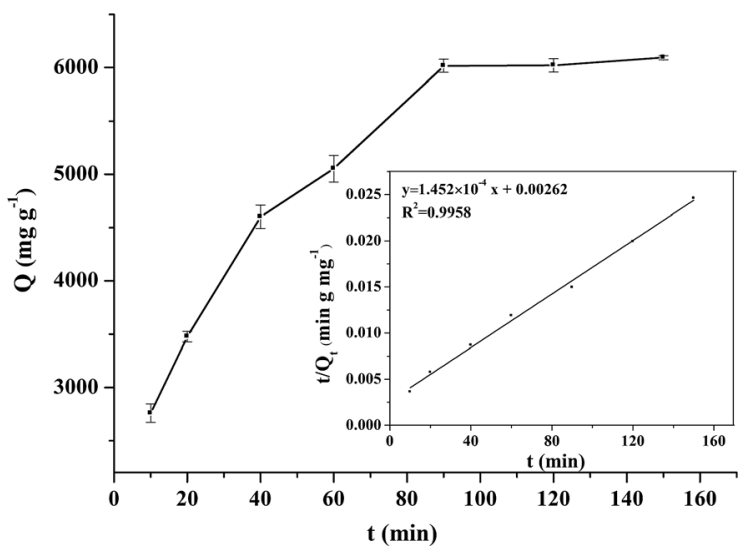

Fig. 6 Adsorption kinetics data and effect of incubation time on $\mathrm{BHb}$ adsorption by $\mathrm{Fe}_{3} \mathrm{O}_{4} @\left[\mathrm{Cu}_{3}(\mathrm{btc})_{2}\right]$ particles $(n=3)$. Experimental conditions: adsorption solution, $20 \mathrm{mM}$ PBS ( $\mathrm{pH}$ 7.0); concentration of $\mathrm{BHb}, 1.8 \mathrm{mg} \mathrm{mL}{ }^{-1}$; volume, $0.2 \mathrm{~mL}$; $\mathrm{Fe}_{3} \mathrm{O}_{4} \mathrm{Q}\left[\mathrm{Cu}_{3}(\mathrm{btc})_{2}\right]$ particles, $0.03 \mathrm{mg}$. applied magnetic field. Further increasing the portion of DEG in the biosolvent system, the prepared particles demonstrated weak magnetic response, which is not favorable for magnetic separation.

Effect of contact time. The influence of contact time on the adsorption performance of $\mathrm{Fe}_{3} \mathrm{O}_{4} @\left[\mathrm{Cu}_{3}(\mathrm{btc})_{2}\right]$ particles for $\mathrm{BHb}$ was optimized while keeping the initial concentration of $\mathrm{BHb}$ at $1.8 \mathrm{mg} \mathrm{mL}{ }^{-1}$, the amount of $\mathrm{Fe}_{3} \mathrm{O}_{4} @\left[\mathrm{Cu}_{3}(\mathrm{btc})_{2}\right]$ at $0.03 \mathrm{mg}$, the adsorption solution at $20 \mathrm{mM}$ PBS (pH 7.0), and total volume at $0.2 \mathrm{~mL}$. As shown in Fig. 6, the adsorbed amount of BHb gradually boosts up along with the increase of contact time until reaching a plateau beyond $90 \mathrm{~min}$. Thus, $90 \mathrm{~min}$ was chosen for the following experiments.

Effect of $\mathbf{p H}$. The effect of adsorption solution $\mathrm{pH}$ ranging from 4.0 to 10.0 on the adsorption efficiency of $\mathrm{Fe}_{3} \mathrm{O}_{4}$ (a) $\left[\mathrm{Cu}_{3}(\mathrm{btc})_{2}\right]$ particles for BHb was recorded. As shown in Fig. 7a, the solution $\mathrm{pH}$ had a remarkable influence on the adsorption of $\mathrm{Fe}_{3} \mathrm{O}_{4} @\left[\mathrm{Cu}_{3}(\mathrm{btc})_{2}\right]$ particles for BHb. The adsorbed amount of $\mathrm{BHb}$ by $\mathrm{Fe}_{3} \mathrm{O}_{4} @\left[\mathrm{Cu}_{3}(\mathrm{btc})_{2}\right]$ particles increased sharply along with the increase of $\mathrm{pH}$ from 4.0 to 7.0. Beyond $\mathrm{pH} 7.0$, the adsorbed amount of BHb decreased quickly. At $\mathrm{pH}$ 7.0, the amount of $\mathrm{BHb}$ adsorbed by $\mathrm{Fe}_{3} \mathrm{O}_{4} @\left[\mathrm{Cu}_{3}(\mathrm{btc})_{2}\right]$ reached maximum. Thus, the adsorption solution ( $\mathrm{pH} 7.0$ ) was used for subsequent experiments.

Effect of ionic strength. The effect of the ionic strength of adsorption solution was studied by changing the
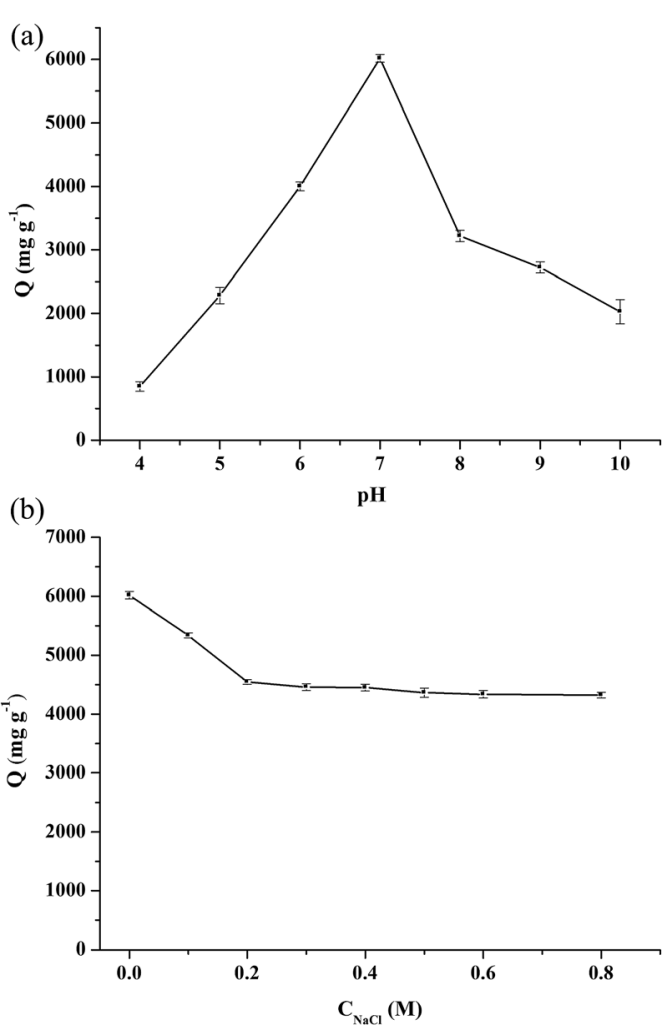

Fig. 7 Effect of $\mathrm{pH}(\mathrm{a})$ and ionic strength (b) on $\mathrm{BHb}$ adsorption by $\mathrm{Fe}_{3} \mathrm{O}_{4} \mathrm{Q}\left[\mathrm{Cu}_{3}(\mathrm{btc})_{2}\right]$ particles $(n=3)$. Experimental conditions: adsorption solution, (a) $20 \mathrm{mM}$ PBS ( $\mathrm{pH} 4.0-10.0$ ), (c) $20 \mathrm{mM}$ PBS ( $\mathrm{pH} 7.0$ ) with different concentrations of $\mathrm{NaCl}$; concentration of $\mathrm{BHb}, 1.8 \mathrm{mg}$ $\mathrm{mL}^{-1}$; $0.03 \mathrm{mg}$; incubation time, $90 \mathrm{~min}$. 


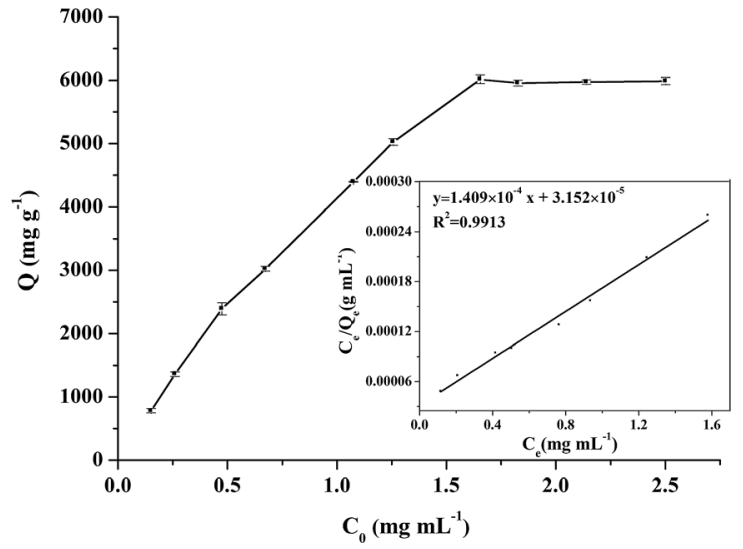

Fig. 8 Isotherm data and effect of initial concentration of $\mathrm{BHb}$ on the adsorbed amount by $\mathrm{Fe}_{3} \mathrm{O}_{4} @\left[\mathrm{Cu}_{3}(\mathrm{btc})_{2}\right]$ particles $(n=3)$. Experimental conditions: adsorption solution, $20 \mathrm{mM}$ PBS (pH 7.0); volume, $0.2 \mathrm{~mL}$; $\mathrm{Fe}_{3} \mathrm{O}_{4} \mathrm{Q}\left[\mathrm{Cu}_{3}(\mathrm{btc})_{2}\right]$ particles, $0.03 \mathrm{mg}$; incubation time, $90 \mathrm{~min}$.

concentrations of $\mathrm{NaCl}$ while keeping the concentration of $\mathrm{BHb}$ at $1.8 \mathrm{mg} \mathrm{mL}^{-1}$. As shown in Fig. 7b, the adsorbed amount of $\mathrm{Fe}_{3} \mathrm{O}_{4} @\left[\mathrm{Cu}_{3}(\mathrm{btc})_{2}\right]$ particles for BHb gradually decreased along with the increase of concentration of $\mathrm{NaCl}$ below $0.2 \mathrm{M}$. Above $0.2 \mathrm{M} \mathrm{NaCl}$, the adsorbed amount of $\mathrm{BHb}$ by $\mathrm{Fe}_{3} \mathrm{O}_{4} @\left[\mathrm{Cu}_{3}(\mathrm{btc})_{2}\right]$ almost remained unchanged. $\mathrm{NaCl}$ in solutions could interfere with the interaction of $\mathrm{BHb}$ and $\mathrm{Fe}_{3} \mathrm{O}_{4} @\left[\mathrm{Cu}_{3}(\mathrm{btc})_{2}\right]$ particles, thus resulting in the decrease of the adsorbed amount of $\mathrm{BHb}$.

Effect of initial concentration of $\mathbf{B H b}$. A series of different concentrations of $\mathrm{BHb}$ solutions ranging from 0.1 to $2.5 \mathrm{mg} \mathrm{mL}^{-1}$ were used to research the adsorption capacity of $\mathrm{Fe}_{3} \mathrm{O}_{4} @$ $\left[\mathrm{Cu}_{3}(\mathrm{btc})_{2}\right]$ particles for $\mathrm{BHb}$. The $\mathrm{Fe}_{3} \mathrm{O}_{4} @\left[\mathrm{Cu}_{3}(\mathrm{btc})_{2}\right]$ particles $(0.03 \mathrm{mg})$ were respectively added to these $\mathrm{BHb}$ solutions. After incubation, the particles were separated by applying an external magnetic field and the amount of $\mathrm{BHb}$ remaining in the supernatant was measured using UV-vis assay at $408 \mathrm{~nm}$. As shown in Fig. 8, the amount of $\mathrm{BHb}$ adsorbed by $\mathrm{Fe}_{3} \mathrm{O}_{4} @\left[\mathrm{Cu}_{3}(\mathrm{btc})_{2}\right]$ particles gradually increased linearly with the increase of the initial concentration of $\mathrm{BHb}$ until reaching a plateau beyond $1.8 \mathrm{mg}$ $\mathrm{mL}^{-1}$. The maximum amount of $\mathrm{BHb}$ adsorbed on $\mathrm{Fe}_{3} \mathrm{O}_{4} @$ $\left[\mathrm{Cu}_{3}(\mathrm{btc})_{2}\right]$ particles was measured to be $6016 \mathrm{mg} \mathrm{g}^{-1}$, which was much larger than that of $\mathrm{Fe}_{3} \mathrm{O}_{4} @ E D T A @ \mathrm{Cu}^{2+}\left(1250 \mathrm{mg} \mathrm{g}^{-1}\right)$ due to the abundance of $\mathrm{Cu}^{2+}$ in $\mathrm{Fe}_{3} \mathrm{O}_{4} @\left[\mathrm{Cu}_{3}(\mathrm{btc})_{2}\right]$.

The role of $\mathrm{Cu}_{3}(\mathrm{btc})_{2}$ in $\mathrm{Fe}_{3} \mathrm{O}_{4} @\left[\mathrm{Cu}_{3}(\mathrm{btc})_{2}\right]$ particles in the recognition of $\mathrm{BHb}$ was also studied by comparing the adsorption capacities of $\mathrm{Fe}_{3} \mathrm{O}_{4}-\mathrm{COOH}$ and $\mathrm{Fe}_{3} \mathrm{O}_{4} @\left[\mathrm{Cu}_{3}(\text { btc })_{2}\right]$ for $\mathrm{BHb}$. The adsorption capacity of $\mathrm{Fe}_{3} \mathrm{O}_{4}-\mathrm{COOH}$ particles for $\mathrm{BHb}$ was measured to be $1169 \mathrm{mg} \mathrm{g}^{-1}$, which was far lower than that of $\mathrm{Fe}_{3} \mathrm{O}_{4} @\left[\mathrm{Cu}_{3}(\mathrm{btc})_{2}\right]$ particles $\left(6016 \mathrm{mg} \mathrm{g}^{-1}\right)$. The result indicated that the existence of abundant binding sites $\left(\mathrm{Cu}^{2+}\right)$ in $\mathrm{Fe}_{3} \mathrm{O}_{4}$ @ $\left[\mathrm{Cu}_{3}(\mathrm{btc})_{2}\right]$ particles and the strong affinity of copper ions for His residues in $\mathrm{BHb}$ resulted in the high adsorption capacity of $\mathrm{Fe}_{3} \mathrm{O}_{4} @\left[\mathrm{Cu}_{3}(\mathrm{btc})_{2}\right]$ for $\mathrm{BHb}$. And the adsorption of $\mathrm{BHb}$ by $\mathrm{Fe}_{3} \mathrm{O}_{4} @\left[\mathrm{Cu}_{3}(\mathrm{btc})_{2}\right]$ was mainly based on the IMAC mechanism.

\section{Adsorption kinetics}

$\mathrm{BHb}$ adsorption kinetics experiments were carried out to assess the adsorption rate of $\mathrm{BHb}$ by $\mathrm{Fe}_{3} \mathrm{O}_{4} @\left[\mathrm{Cu}_{3}(\mathrm{btc})_{2}\right]$, as shown in
Fig. 6. In order to describe the behavior of $\mathrm{BHb}$ adsorption, pseudo-first-order and pseudo-second-order kinetic models were used to fit the experimental data. The pseudo-first-order and pseudo-second-order models can be expressed as eqn (2) and (3), respectively:

$$
\begin{gathered}
\ln \left(Q_{\mathrm{e}}-Q_{\mathrm{t}}\right)=\ln Q_{\mathrm{e}}-k_{1} t \\
\frac{t}{Q_{\mathrm{t}}}=\frac{1}{k_{2} Q_{\mathrm{e}}^{2}}+\frac{t}{Q_{e}}
\end{gathered}
$$

where $k_{1}\left(\min ^{-1}\right)$ and $k_{2}\left(\mathrm{~g} \mathrm{mg}^{-1} \mathrm{~min}^{-1}\right)$ are the pseudo-firstorder rate constant and pseudo-second-order rate constant, respectively. $Q_{\mathrm{t}}\left(\mathrm{mg} \mathrm{g}^{-1}\right)$ and $Q_{\mathrm{e}}\left(\mathrm{mg} \mathrm{g}^{-1}\right)$ are the adsorbed amounts of $\mathrm{BHb}$ at any and equilibrium time, respectively. When the experimental data were fitted to eqn (2), an equation $\ln \left(6016-Q_{\mathrm{t}}\right)=8.321-2.48 \times 10^{-2} t$ with determination coefficient $\left(R^{2}\right)$ of 0.9879 was obtained. When the experimental data were fitted to eqn (3), an equation $t / Q_{\mathrm{t}}=1.452 \times 10^{-4} t+$ 0.00262 with $R^{2}$ of 0.9958 was obtained. The higher $R^{2}$ value indicated that pseudo-second-order kinetic model $\left(R^{2}=0.9958\right)$ was more appropriate to describe the adsorption process of $\mathrm{BHb}$ than pseudo-first-order kinetic model $\left(R^{2}=0.9879\right)$.

\section{Adsorption isotherm}

Adsorption isotherm experiments were performed to investigate the adsorption capacity of $\mathrm{Fe}_{3} \mathrm{O}_{4} @\left[\mathrm{Cu}_{3}(\mathrm{btc})_{2}\right]$ particles for $\mathrm{BHb}$, as shown in Fig. 8. Freundlich and Langmuir models were used to analyze the adsorption process of $\mathrm{BHb}$ and their models can be expressed as eqn (4) and (5), respectively:

$$
\begin{gathered}
\ln Q_{\mathrm{e}}=\ln K_{\mathrm{F}}+\frac{1}{n} \ln C_{\mathrm{e}} \\
\frac{C_{\mathrm{e}}}{Q_{\mathrm{e}}}=\frac{C_{\mathrm{e}}}{Q_{\mathrm{m}}}+\frac{1}{K_{\mathrm{L}} Q_{\mathrm{m}}}
\end{gathered}
$$

where $K_{\mathrm{F}}\left(\mathrm{mg} \mathrm{g}^{-1}\right)$ and $1 / n$ are the Freundlich characteristic constants, reflecting the adsorption capacity and the adsorption intensity, respectively. $Q_{\mathrm{e}}\left(\mathrm{mg} \mathrm{g}^{-1}\right)$ is the amount of $\mathrm{BHb}$ adsorbed at equilibrium time, $Q_{\mathrm{m}}\left(\mathrm{mg} \mathrm{g}^{-1}\right)$ is the maximum adsorption amount of $\mathrm{BHb}, K_{\mathrm{L}}\left(\mathrm{mL} \mathrm{mg}^{-1}\right)$ is related to the energy of adsorption, and $C_{\mathrm{e}}\left(\mathrm{mg} \mathrm{mL}^{-1}\right)$ is the equilibrium concentration of $\mathrm{BHb}$ in solution.

The relationship of $\ln Q_{\mathrm{e}}$ against $\ln C_{\mathrm{e}}$ was expressed as an equation, $\ln Q_{\mathrm{e}}=0.4643 \ln C_{\mathrm{e}}+8.787\left(R^{2}=0.9848\right)$. A plot of $C_{\mathrm{e}} / Q_{\mathrm{e}}$ versus $C_{\mathrm{e}}$ was expressed as an equation, $C_{\mathrm{e}} / Q_{\mathrm{e}}=1.409 \times$ $10^{-4} C_{\mathrm{e}}+3.152 \times 10^{-5}\left(R^{2}=0.9913\right)$. The $R^{2}$ for Langmuir model (0.9913) was greater than that for Freundlich model (0.9848), indicating that $\mathrm{BHb}$ adsorption was better described by the Langmuir model. And $\mathrm{BHb}$ could be adsorbed on $\mathrm{Fe}_{3} \mathrm{O}_{4}$ @ $\left[\mathrm{Cu}_{3}(\mathrm{btc})_{2}\right]$ surface as a monolayer adsorption.

\section{Selectivity of $\mathrm{Fe}_{3} \mathrm{O}_{4} @\left[\mathrm{Cu}_{3}(\mathrm{btc})_{2}\right]$ particles for $\mathrm{BHb}$}

In order to investigate the selectivity of $\mathrm{Fe}_{3} \mathrm{O}_{4} @\left[\mathrm{Cu}_{3}(\mathrm{btc})_{2}\right]$ particles towards $\mathrm{BHb}$, Lyz and BSA were selected as the comparative proteins. The adsorption capacities of $\mathrm{Fe}_{3} \mathrm{O}_{4}$ @ $\left[\mathrm{Cu}_{3}(\mathrm{btc})_{2}\right]$ towards BSA and Lyz were measured to be $206.5 \mathrm{mg}$ $\mathrm{g}^{-1}$ and $594.5 \mathrm{mg} \mathrm{g}^{-1}$, respectively, under the optimized 

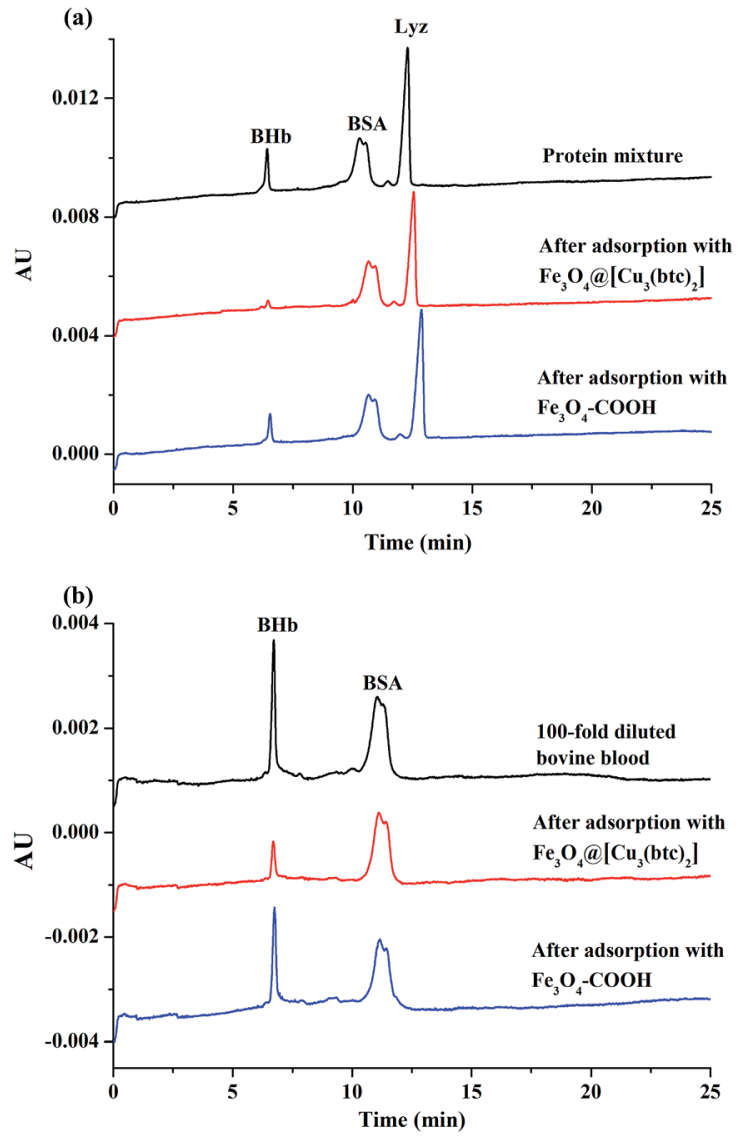

Fig. 9 Analysis of proteins mixture (a), and bovine blood (b) by CE. CE experimental conditions: separation buffer, 20 mM PBS ( $\mathrm{pH}$ 2.5); PDA coated capillary, $39.2 \mathrm{~cm}$ (effective length $29.2 \mathrm{~cm}$ ) $\times 50 \mu \mathrm{m}$ i.d; applied voltage, $-20 \mathrm{kV}$; injection, $0.5 \mathrm{psi} \times 5 \mathrm{~s}$; UV detection, $214 \mathrm{~nm}$.

adsorption conditions for BHb. The adsorption capacity of $\mathrm{Fe}_{3} \mathrm{O}_{4} @\left[\mathrm{Cu}_{3}(\mathrm{btc})_{2}\right]$ particles for $\mathrm{BHb}$ was much larger than those of comparative proteins, demonstrating that $\mathrm{Fe}_{3} \mathrm{O}_{4} @\left[\mathrm{Cu}_{3}(\mathrm{btc})_{2}\right]$ particles possessed high selectivity for $\mathrm{BHb}$. The difference in the adsorption capacities of $\mathrm{Fe}_{3} \mathrm{O}_{4} @\left[\mathrm{Cu}_{3}(\mathrm{btc})_{2}\right]$ for proteins was likely due to the difference in the metal ion chelation, as well as electrostatic and hydrophobic interactions between proteins and $\mathrm{Fe}_{3} \mathrm{O}_{4} @\left[\mathrm{Cu}_{3}(\mathrm{btc})_{2}\right] .^{12}$ Metal ion chelation based on the interaction between electron donor groups and the immobilized metal ions is specific. In contrast, hydrophobic forces and electrostatic interactions between hydrophobic sites and the charged proteins and the negatively charged on the $\mathrm{Fe}_{3} \mathrm{O}_{4}$ @ $\left[\mathrm{Cu}_{3}(\mathrm{btc})_{2}\right]$ are nonspecific. BHb is a His-rich protein containing 20 surface-exposed His residues, whereas BSA contains 2 surface-exposed His residues and Lyz has no surface-exposed His residues. ${ }^{37,38}$ Consequently, $\mathrm{Fe}_{3} \mathrm{O}_{4} @\left[\mathrm{Cu}_{3}(\mathrm{btc})_{2}\right]$ particles possessed high selectivity for His-rich protein $\mathrm{BHb}$ mainly based on IMAC mechanism.

A protein mixture containing BHb, BSA and Lyz $(0.2 \mathrm{~mL}$, $0.5 \mathrm{mg} \mathrm{mL} \mathrm{mL}^{-1}$ for each protein) was used as one sample to evaluate the selectivity of $\mathrm{Fe}_{3} \mathrm{O}_{4} @\left[\mathrm{Cu}_{3}(\mathrm{btc})_{2}\right]$ particles towards His-rich proteins. The protein mixture and the supernatant after adsorption and magnetic separation were analyzed by $\mathrm{CE}$, as described in Fig. 9a. After treatment by $\mathrm{Fe}_{3} \mathrm{O}_{4} @\left[\mathrm{Cu}_{3}(\mathrm{btc})_{2}\right]$ particles $(0.03 \mathrm{mg}), 87.7 \%$ of $\mathrm{BHb}$ was removed from the mixture with minor loss of BSA and Lyz $(91.4 \%$ of BSA and $79.4 \%$ of Lyz were remained). When the mixture solution was treated by $\mathrm{Fe}_{3} \mathrm{O}_{4}-\mathrm{COOH}$ particles, only $33.9 \%$ of $\mathrm{BHb}$ was removed and little adsorption of the particles for the two comparative proteins was found.

\section{Real sample analysis}

Bovine blood sample was used to further evaluate the feasibility of $\mathrm{Fe}_{3} \mathrm{O}_{4} @\left[\mathrm{Cu}_{3}(\mathrm{btc})_{2}\right]$ particles in real biological samples. Firstly, the 100-fold diluted blood samples were incubated with $\mathrm{Fe}_{3} \mathrm{O}_{4} @\left[\mathrm{Cu}_{3}(\mathrm{btc})_{2}\right]$ and $\mathrm{Fe}_{3} \mathrm{O}_{4}-\mathrm{COOH}$ particles for $90 \mathrm{~min}$, respectively. Then the diluted blood sample and the supernatants after adsorption were analyzed by CE. As shown in Fig. 9b, after treatment with $\mathrm{Fe}_{3} \mathrm{O}_{4} @\left[\mathrm{Cu}_{3}(\mathrm{btc})_{2}\right]$ particles $(0.03 \mathrm{mg}$ ), $83.4 \%$ of $\mathrm{BHb}$ in the diluted bovine blood sample were removed, while less than $4.95 \%$ of BSA were adsorbed by the particles. By contrast, the $\mathrm{Fe}_{3} \mathrm{O}_{4}-\mathrm{COOH}$ particles removed less than $39.4 \%$ of $\mathrm{BHb}$ and $3.87 \%$ of BSA. The results demonstrated that the as-prepared $\mathrm{Fe}_{3} \mathrm{O}_{4} @\left[\mathrm{Cu}_{3}(\mathrm{btc})_{2}\right]$ particles possessed high selectivity for hemoglobin and were promising adsorbents to remove His-rich proteins from real complex samples.

\section{Conclusions}

An approach was developed to fabricate magnetic $\mathrm{Fe}_{3} \mathrm{O}_{4}$ @ $\left[\mathrm{Cu}_{3}(\mathrm{btc})_{2}\right]$ nanocomposites, which were applied for adsorption of His-rich proteins. The $\mathrm{Fe}_{3} \mathrm{O}_{4} @\left[\mathrm{Cu}_{3}(\mathrm{btc})_{2}\right]$ particles possessed good magnetic response. As expected, they exhibited a high adsorption capacity and good adsorption selectivity for $\mathrm{BHb}$ due to the existence of a wealth of copper ions in the $\mathrm{Cu}_{3}(\mathrm{btc})_{2}$ shell and the strong affinity of copper ions towards His residues. The adsorption equilibrium can be achieved in $90 \mathrm{~min}$ and the adsorption capacity of $\mathrm{BHb}$ was up to $6016 \mathrm{mg} \mathrm{g}^{-1}$. In comparison with other functionalized magnetic adsorbents which aimed at the adsorption of $\mathrm{BHb}$ (Table 1), $\mathrm{Fe}_{3} \mathrm{O}_{4} @$ $\left[\mathrm{Cu}_{3}(\mathrm{btc})_{2}\right]$ particles demonstrated superiority in adsorption capacity. Besides, $\mathrm{Fe}_{3} \mathrm{O}_{4} @\left[\mathrm{Cu}_{3}(\mathrm{btc})_{2}\right]$ particles can selectively remove highly abundant hemoglobin from bovine blood. It is

Table 1 Figures of merits of various magnetic adsorbents for $\mathrm{BHb}$ adsorption

\begin{tabular}{|c|c|c|c|}
\hline Materials & $\begin{array}{l}\text { Maximum } \\
\text { adsorption capacity } \\
\left(\mathrm{mg} \mathrm{g}^{-1}\right)\end{array}$ & $\begin{array}{l}\text { Adsorption } \\
\text { time } \\
\text { (h) }\end{array}$ & Reference \\
\hline $\begin{array}{l}\mathrm{Cu}^{2+} \text {-IDA-poly } \\
\text { (methacrylate- } \\
\text { divinylbenzene) }-\mathrm{Fe}_{3} \mathrm{O}_{4}\end{array}$ & 168.2 & 2 & 10 \\
\hline $\mathrm{Cu}^{2+}-\mathrm{IDA}-\mathrm{SiO}_{2}-\mathrm{Fe}_{3} \mathrm{O}_{4}$ & 418.6 & 5 & 13 \\
\hline $\begin{array}{l}\mathrm{Zn}^{2+}-\mathrm{IDA}-\text { poly } \\
\text { (glycidyl } \\
\text { methacrylate) }-\mathrm{Fe}_{3} \mathrm{O}_{4}\end{array}$ & 260 & 2 & 14 \\
\hline $\mathrm{Fe}_{3} \mathrm{O}_{4} @ E D T A @ \mathrm{Cu}^{2+}$ & 1250 & 1.0 & 33 \\
\hline $\mathrm{Fe}_{3} \mathrm{O}_{4} @\left[\mathrm{Cu}_{3}(\mathrm{btc})_{2}\right]$ & 6016 & 1.5 & This work \\
\hline
\end{tabular}


expected that $\mathrm{Fe}_{3} \mathrm{O}_{4} @\left[\mathrm{Cu}_{3}(\text { btc })_{2}\right]$ particles have potential applications in removal of abundant His-rich proteins in biomedical diagnosis analysis.

\section{Acknowledgements}

We are grateful to the financial support of the National Natural Science Foundation of China (21675056) and Natural Science Foundation of Guangdong Province (2015A030311013).

\section{Notes and references}

1 M. Rowinska-Zyrek, D. Witkowska, S. Potocki, M. Remelli and H. Kozlowski, New J. Chem., 2013, 37, 58-70.

2 D. J. Sullivan Jr, I. Y. Gluzman and D. E. Goldberg, Science, 1996, 271, 219-222.

3 A. L. Jones, M. D. Hulett and C. R. Parish, Immunol. Cell Biol., 2005, 83, 106-118.

4 E. K. M. Ueda, P. W. Gout and L. Morganti, J. Chromatogr. A, 2003, 988, 1-23.

5 X. M. He, G. T. Zhu, W. Lu, B. F. Yuan, H. Wang and Y. Q. Feng, J. Chromatogr. A, 2015, 1405, 188-192.

6 M. Petzold, C. J. Coghlan and M. T. W. Hearn, J. Chromatogr. A, 2014, 1351, 61-69.

7 S. Wang, N. Xiong, X. Y. Dong and Y. Sun, J. Chromatogr. A, 2013, 1320, 118-124.

8 R. X. Gao, L. L. Zhang, Y. Hao, X. H. Cui and Y. H. Tang, RSC Adv., 2014, 4, 64514-64524.

9 Z. Zhang, J. H. Li, J. Q. Fu and L. X. Chen, RSC Adv., 2014, 4, 20677-20685.

10 Z. Y. Ma, Y. P. Guan, X. Q. Liu and H. Z. Liu, J. Appl. Polym. Sci., 2005, 96, 2174-2180.

11 Z. Rashid, H. Naeimi, A. H. Zarnani, M. Nazari, M. R. Nejadmoghaddam and R. Ghahremanzadeh, RSC Adv., 2016, 6, 36840-36848.

12 Y. Q. Liao, Y. J. Cheng and Q. G. Li, J. Chromatogr. A, 2007, 1143, 65-71.

13 M. Zhang, D. Cheng, X. W. He, L. X. Chen and Y. K. Zhang, Chem.-Asian J., 2010, 5, 1332-1340.

14 W. S. Li, L. R. Yang, H. C. Zhou, X. P. Li, F. C. Wang, X. F. Yang and H. Z. Liu, Ind. Eng. Chem. Res., 2013, 52, 16314-16320.

15 G. Q. Jian, Y. X. Liu, X. W. He, L. X. Chen and Y. K. Zhang, Nanoscale, 2012, 4, 6336-6342.

16 J. L. Cao, X. H. Zhang, X. W. He, L. X. Chen and Y. K. Zhang, J. Mater. Chem. B, 2013, 1, 3625-3632.

17 C. J. Xu, K. M. Xu, H. W. Gu, X. F. Zhong, Z. H. Guo, R. K. Zheng, X. X. Zhang and B. Xu, J. Am. Chem. Soc., 2001, 126, 3392-3393.
18 C. J. Xu, K. M. Xu, H. W. Gu, R. K. Zheng, H. Liu, X. X. Zhang, Z. H. Guo and B. Xu, J. Am. Chem. Soc., 2004, 126, 9938-9939.

19 V. Jabbari, J. M. Veleta, M. Zarei-Chaleshtori, J. GardeTorresdey and D. Villagrán, Chem. Eng. J., 2016, 304, 774783.

20 J. W. Yoon, S. H. Jhung, Y. K. Hwang, S. M. Humphrey, P. T. Wood and J. S. Chang, Adv. Mater., 2007, 19, 1830-1834.

21 L. Bastin, P. S. Bárcia, E. J. Hurtado, J. A. C. Silva, A. E. Rodrigues and B. L. Chen, J. Phys. Chem. C, 2008, 112, 1575-1581.

22 J. Y. Lee, O. K. Farha, J. Roberts, K. A. Scheidt, S. B. T. Nguyen and J. T. Hupp, Chem. Soc. Rev., 2009, 38, 1450-1459.

23 D. Zhao, D. J. Timmons, D. Q. Yuan and H. C. Zhou, Acc. Chem. Res., 2010, 44, 123-133.

24 W. J. Li, S. Y. Gao, T. F. Liu, L. W. Han, Z. J. Lin and R. Cao, Langmuir, 2013, 29, 8657-8664.

25 R. J. Della, D. Liu and W. Lin, Acc. Chem. Res., 2011, 44, 957968.

26 J. Y. Lee, C. Y. Y. Tang and F. W. Huo, Sci. Rep., 2014, 4, 3740.

27 M. O. Aziz-Zanjani and A. Mehdinia, Microchim. Acta, 2014, 181, 1169-1190.

28 S. H. Huo and X. P. Yan, Analyst, 2012, 137, 3445-3451.

29 Y. L. Hu, Z. L. Huang, J. Liao and G. K. Li, Anal. Chem., 2013, 85, 6885-6893.

30 X. Q. Yang, C. X. Yang and X. P. Yan, J. Chromatogr. A, 2013, 1304, 28-33.

31 X. F. Chen, N. Ding, H. Zang, H. Yeung, R. S. Zhao, C. G. Cheng, J. H. Liu and T. W. D. Chan, J. Chromatogr. A, 2013, 1304, 241-245.

32 Y. J. Chen, Z. C. Xiong, L. Peng, Y. Y. Gan, Y. M. Zhao, J. Shen, J. H. Qian, L. Y. Zhang and W. B. Zhang, ACS Appl. Mater. Interfaces, 2015, 7, 16338-16347.

33 C. Ding, X. Ma, X. Yao and L. Jia, J. Chromatogr. A, 2015, 1424, 18-26.

34 S. Xuan, Y. X. J. Wang, J. C. Yu and K. C. F. Leung, Chem. Mater., 2009, 21, 5079-5087.

35 X. Xiao, W. Wang, J. Chen and L. Jia, J. Sep. Sci., 2015, 38, 2893-2899.

36 X. Wang, X. B. Lu, L. D. Wu and J. P. Chen, Biosens. Bioelectron., 2015, 65, 295-301.

37 G. E. Wuenschell, E. Naranjo and F. H. Arnold, Bioprocess Eng., 1990, 5, 199-202.

38 E. S. Hemdan, Y. J. Zhao, E. Sulkowski and J. Porath, Proc. Natl. Acad. Sci. U. S. A., 1989, 86, 1811-1815. 